Donnabel B. Bihasa, 2022

Volume 5 Issue 3, pp. 220-237

Received: $14^{\text {th }}$ May 2021

Revised: 14 ${ }^{\text {th }}$ August 2021, 25 th September 2021, 24 th January 2022

Accepted: 30th January 2022

Date of Publication: 08 $8^{\text {th }}$ February 2022

DOI- https://doi.org/10.20319/pijtel.2022.53.220237

This paper can be cited as: Bihasa, D. B. (2022). The Preparedness of Pre-Service Teachers on The Required Programs to Meet Standards. PUPIL: International Journal of Teaching, Education and Learning, 5 (3),220-237.

This work is licensed under the Creative Commons Attribution-NonCommercial 4.0 International License. To view a copy of this license, visit http://creativecommons.org/licenses/by-nc/4.0/ or send a letter to Creative Commons, PO Box 1866, Mountain View, CA 94042, USA.

\title{
THE PREPAREDNESS OF PRE-SERVICE TEACHERS ON THE REQUIRED PROGRAMS TO MEET STANDARDS
}

\author{
Donnabel B. Bihasa \\ Senior Education Program Specialist, Teacher Education Council Secretariat, Department of \\ Education, Pasig City, Philippines \\ PhD Student, Emilio Aguinaldo College, Paco, Manila, Philippines \\ dbbihasa.mnl@eac.edu.ph
}

\begin{abstract}
"A quality education begins with the best teachers", Pyne, 2014. Capacitating the teaching force helps in the improvement of learners' performance. Attracting the best educators in the profession, where respect, nobility, and prestige were sustained by exhibiting quality teaching to produce the best output or performance and an untiring motivation for student's learning will have a positive impact. As an educator let us live by this famous quote, "Teaching is the noblest profession" and uphold its meaning by being a model to our learners. This qualitative study which involved three participants tried to scrutinize the preparedness of the PSTs on the required teacher preparation programs to meet standards offered by the Department and use descriptive narrative to treat the gathered data. It also explored the practices of the TEIs in preparation for the challenges of the pre-service teachers when they are already in the school. The results of this study stated that there is already familiarity among the pre-service teachers on the existing programs offered by the
\end{abstract}


department for the professional learning and development of in-service teachers. And the preservice teachers planned to engage and participate in continuing education, school learning action cells, in-service training, seminars, and workshops for upskilling and reskilling and for professional development.

\section{Keywords}

Pre-Service Teachers (PSTs), Professional Learning (PL), Professional Development (PD), Professional Standards (PS)

\section{Introduction}

"A quality education begins with the best teachers", Pyne, 2014, this was also mentioned and elaborated during the gathering of the American Association of School Administrators and The American Federation of Teachers. An empowered teacher will also create an empowered learner. Education Policy in Japan as stated in OECD (2018) mentioned that teaching quality is widely recognized as the most essential in-school factor affecting student learning. Furthermore, improving teaching quality begins by attracting the best to the profession. One way to do this is to ensure that the teaching profession is respected.

International Literacy Association (ILA) 2020 Report which was participated by 1,443 total respondents from 65 countries and territories stated the different top critical topics for improving literacy outcomes in the next new decade in which requiring teacher preparation programs to meet rigorous standards is one of those mentioned with $23 \%$ or included in the top 10 topics that are critical in improving literacy outcomes.

Creating and providing the latest and remarkable teaching and learning experiences to the learners to improve their literacy outcomes were a product of teachers' professional learning and continuous offering for professional development. It is said that when teachers are provided with competent, constant professional learning experiences they are more likely to inspire pupils and provide the best teaching and learning experiences that enable learners to achieve their best. DepEd Order No.43, s. 2017 stated that continuing development and progress of the newly hired teachers is based on the principle of lifelong learning and the Department's commitment to the development of new and beginning teachers. This is also supported by DepEd Order No. 42, s. 2017 or The Implementation of the Philippine Professional Standards for Teachers which recognizes the importance of professional standards in the continuing professional development and advancement of teachers based on the principle of lifelong learning. Furthermore, it is also committed to 
supporting teachers and taking cognizance of unequivocal evidence that good teachers are vital to raising student achievement.

\subsection{Literature Review}

According to Noida, 2021 schools have recognized that educational technology is essential in preparing students for a rapidly changing world. Educators learn new teaching methods and constantly strive to innovate.

In Japan, lifelong learning (adult education, continuing education, professional development, and skills training) is a means of boosting productivity, reducing human capital depreciation, improving workers' outcomes in the labor market, and helping them to enjoy a better life. It can also be used as a way of developing and enhancing workers' non-cognitive or "soft" skills, which are increasingly valued by employers (OECD, 2016g).

Travis, 2020 pointed out that learning professionals need to take a grip and enjoy the benefits of having technology which plays an important role in education, they need to confront the other side of educational technology and openly challenge the "new shiny objects" emerging in the market every day. We need to watch out and learn as the first-raised tech generation is entering the workforce.

The workplace of today's generation is challenging and demanding. Whether it is in business or the education sector. As an educator, how are you going to face the digital divide? Is the $21^{\text {st }}$-century education you learned and the $21^{\text {st }}$-century skills you acquired are sufficient?

In the Philippine context in offering professional standards, Tertiary Education Institutions (TEIs) which offered Teacher Education abides by the CHED Memorandum Order which presents the policies, standards, and guidelines in which also anchored the salient features of $\mathrm{K}$ to 12 Enhanced Curriculum (RA 10533), the Philippine Qualifications Framework (EO 83, s. 2012), the National Competency-Based Teacher Standards (NCBTS) and now the Philippine Professional Standards for Teachers (D.O.42, s. 2017) which specifies the core competencies expected from the graduates of a particular discipline.

The credentials of model programs and the rising percentage of teacher preparation programs that meet the professional standards appear to the impact that they have had in encouraging reform. Garcia, et.al, 2018; Dhonau, McAlpine, \& Shrun, 2008; Glisan, Swender, \& Surface, 2013; Huhn, 2012; Shrum \& Fox, 2010. 
According to Darling-Hammond \& Young, 2002, research demonstrates that teachers' preparation and qualifications are the most predicative gauges of student achievement and lasting academic success.

In the study conducted by Schnabel, 2009, the long-term effects of students being taught by underqualified teachers may be expressed in sadly low graduation rates and disparately low post-secondary enrollments.

As explained by Wilson, et. Al, 2001, numerous studies have shown an affirmative relationship between teacher qualifications and students outcomes. This connection supports the view that teacher preparation and certification are authentic criteria for entry into the profession.

Owsiak, N.K. 2008 mentioned Kezar, 2001, pointed out that leaders more directly involved with teacher preparation activities, such as department heads or directors of teacher education programs are "closer to the action" and perceive policy implementation through different lenses.

The findings of the study of Sox, 2011 highlight that quality teacher education must also be addressed across the content areas, not just for those seeking middle-grade licensure. Furthermore, those with other types of licensures reported feeling less knowledgeable about other areas. Specific professional development had been historically absent from their professional development, except those who had been trained.

Brisk \& Zisselberger, 2011 stated that collaboration was the most commonly discussed professional development option. Collaboration is a helpful tool for providing the follow-through necessary for changing teachers' practices.

\subsection{Research Issues}

The researcher was interested in conducting this study to determine the status of readiness of the pre-service teachers which will help the mentors, school administrators, and the education agencies to calibrate curriculum, adopt or impose standards that are suited and easy to embrace by the pre-service teachers to boost their potential and be a big contributor in giving quality education to our learners.

This undertaking tried to scrutinize the preparedness of the pre-service teachers on the required teacher preparation programs to meet rigorous standards offered by the Department of Education. In addition, it will also explore the practices of the TEIs in preparation for the challenges of the pre-service teachers as they will face their future station - the school. 
The framework of this study was anchored on the Department of Education Order No. 42, s. 2017 or the National Adoption and Implementation of the Philippine Professional Standards for Teachers (PPST). PPST as the New Framework for Teacher Quality and Teacher Development was adopted by Research Center for Teacher Quality (RCTQ). This follows several stages: Stage 1 (Beginning) Stage 2 (Proficient) Stage 3 (Highly Proficient) Stage 4 (Distinguished).

Such theory is backed up by the concept of DepEd Order No. 1, s. 2020 or the Guidelines for NEAP Recognition of Professional Development Programs and Courses for Teachers and School Leaders. The quality of professional development programs and courses shall be assured through a Recognition System that requires alignment to professional standards for teachers and school leaders, responsiveness to identified professional development priorities, promotion of dynamism, innovation, and application at the classroom level, and transparency and consistency.

Therefore, the researcher determined the profile of the pre-service teacher respondents in terms of personal / background (age, region, school, status of school, reason in pursuing teacher education); training, pedagogy, and expectations; and, readiness and preparedness through an online survey and set for a virtual interview to selected respondents to confirm their answers. The selected pre-service teacher who underwent the virtual interview was the first ten respondents who answered the online survey.

This study was limited only to the pre-service teachers who underwent the internship or field study or simply those who are graduating students.

This study was designed to benefit the following: Teacher - mentors who helped and guide the pre-service teachers during their internship and field study and be aware of the needs of the PSTs. School Administrators who implement different policies prescribed by education agencies and be mindful of the demand of the education market and equip the PSTs with these skills by integrating the demand skills in the school policy, and the different education agencies who crafted and designed policies for our PSTs. That they should revisit the curriculum and the policies and guidelines which may not be the demand of the society and try to listen to the voice of the PSTs and the demand of the market to avoid mismatch on the different specialization. For the intended readers to fully understand the paper, the researcher has given both the conceptual and operational definitions of the terms used in this paper.1) Pre-service Teachers (PSTs). As used in this study, it refers to students who are taking Teacher Education, particularly those who are undergoing Internship or Field Study. 2) Professional Standards. As used in this study, it refers to the set of 
professional attributes, knowledge, and skills that a teacher must possess. It particularly pertains to the Philippine Professional Standards for Teachers. 3) Philippine Professional Standards for Teachers. As used in this study, it refers to the source for learning and development programs for teachers to certify that teachers are properly equipped to effectively implement the $\mathrm{K}$ to 12 Program. 4) Professional Development(PD). As used in this study, it refers to the training, programs, or courses taken by teachers for improvement professionally. 5) Teacher Education (TE). As used in this study, it refers to the policies, procedures, and provisions designed to equip potential teachers with the knowledge, attitudes, behaviors, and skills they require to perform their tasks effectively in the classroom, school, and wider community.

\section{Methodology}

This part of the paper includes the when, where, and how the study is done, materials used, and the participants of the study.

This research used the descriptive narrative which is focused on a simple qualitative research design. Qualitative research is an advancement to a deeper understanding of an event, organization, or culture, which gives a wide understanding of events, data about human groups, and expansive patterns behind events and people, and allows the meaning, themes, or data to emerge from the study. Further, it uses non-statistical methods to increase understanding of the population. According to the Handbook of Research Methodology (2017), there are three advantages of a descriptive method such as (1) effective to evaluate non-quantified topics and issues; (2) there is a chance to observe the curiosity in a completely natural environment and (3) there is a way to combine the qualitative and quantitative methods of data collection.

This study was done in the Philippines focusing on the Pre-service Teachers in the Tertiary Education Institutions (TEIs) particularly those schools/colleges/universities with the Center of Excellence (COE) and Center of Development (COD) status.

This study utilized the online survey through Google forms which was supported by a virtual interview of the selected participants.

Participants were pre-selected by their mentors/ professors and took the online survey. They were the first 10 students coming from their Field Study class or Internship class.

The researcher strictly observed the following ethical considerations including privacy, concealment, approval, and the researchers' potential impact on the participants and vice versa. It 
is of great importance that participants/informants are well informed of all the different aspects of their roles or acting as the participants of this qualitative research. Hence, these roles need to be well defined, and the use of real and useful guidelines and protocols in all stages of qualitative studies should be encouraged.

\section{Results, Analysis, and Discussion}

The gathered data are presented here together with the analysis and interpretation based on the stated objectives of the study. These include the profile of the pre-service teacher respondents in terms of personal / background (age, region, school, status of school, reason in pursuing teacher education); training, pedagogy, and expectations; and readiness and preparedness.

Figures 1 to 3 present the graph of the participants' profile in terms of their age, region, and status of school/ college/university they belong

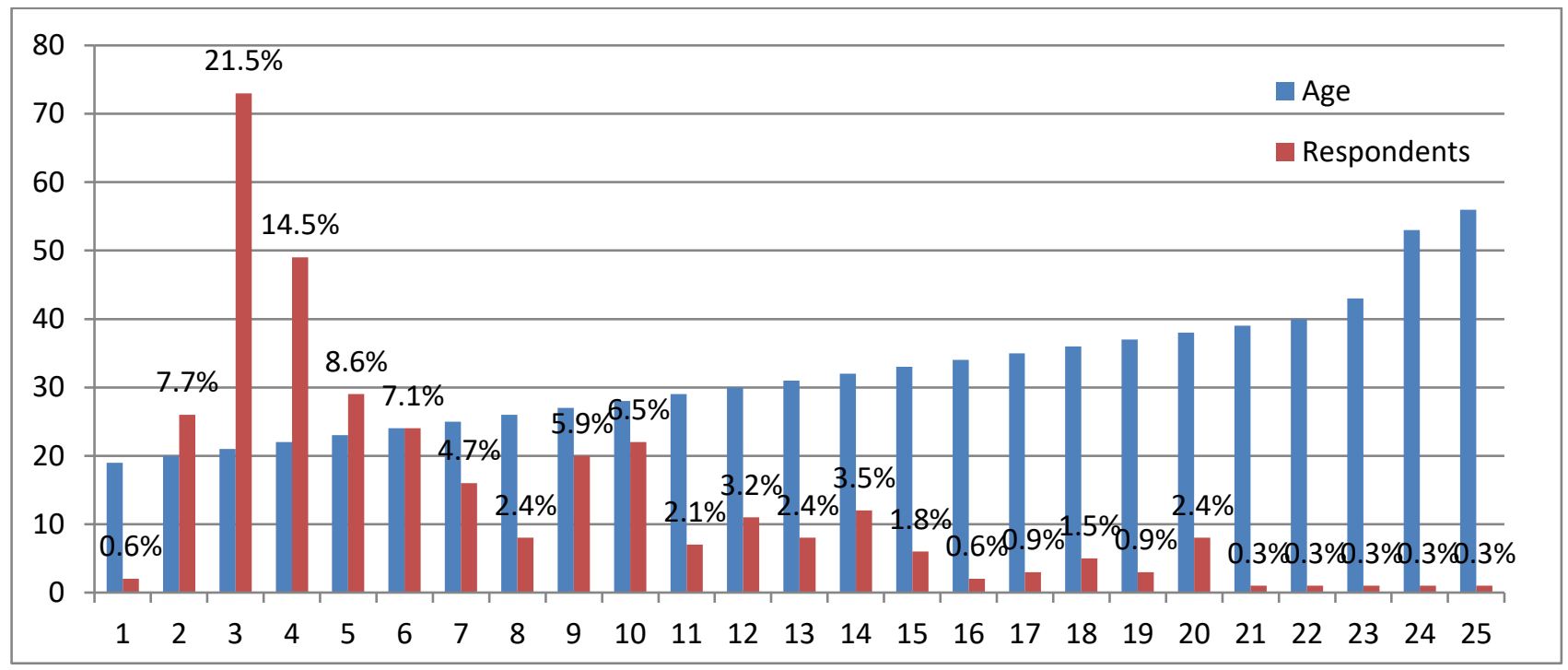

Figure 1: Age

(Source: Survey on The Preparedness of Pre-Service Teachers on the Required Teacher

\section{Preparation Programs to Meet Rigorous Standards)}

In terms of age, the participants belong to aged 21 and 22 with a percentage of $30.6 \%$ and $16.1 \%$, respectively. 


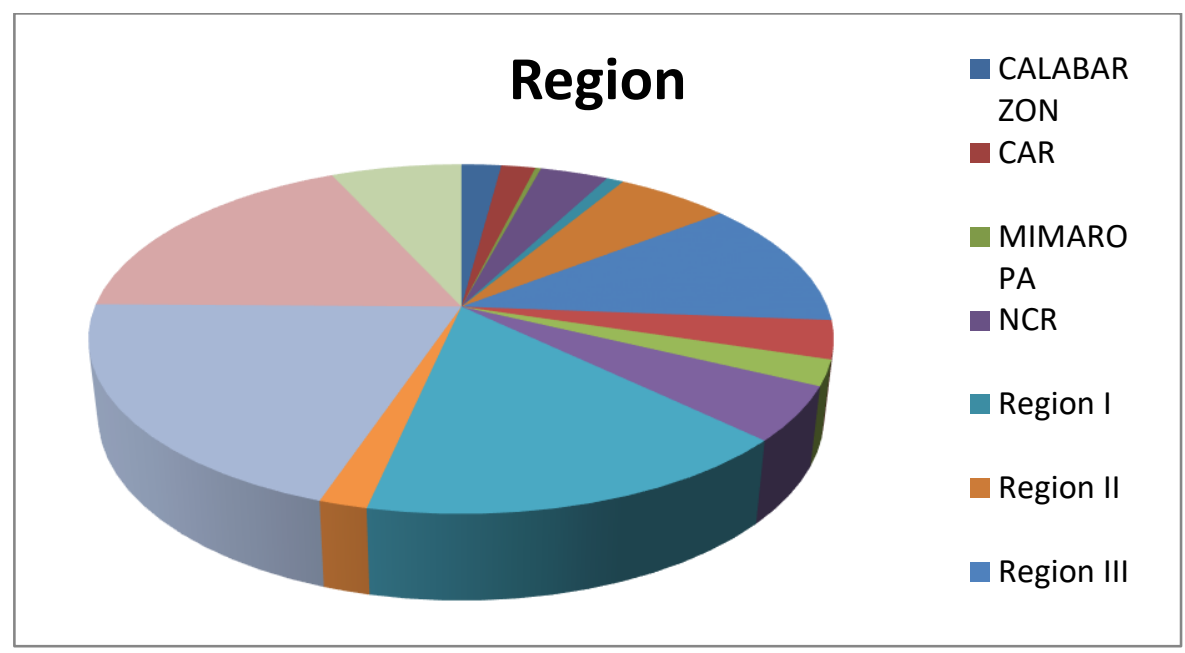

Figure 2: Region

(Source: Survey on The Preparedness of Pre-Service Teachers on the Required Teacher Preparation Programs to Meet Rigorous Standards)

In terms of locality, $32.5 \%$ of the participants came from Region VIII, followed by Region $\mathrm{X}$ with $26.2 \%$ and Region III with $21.4 \%$.

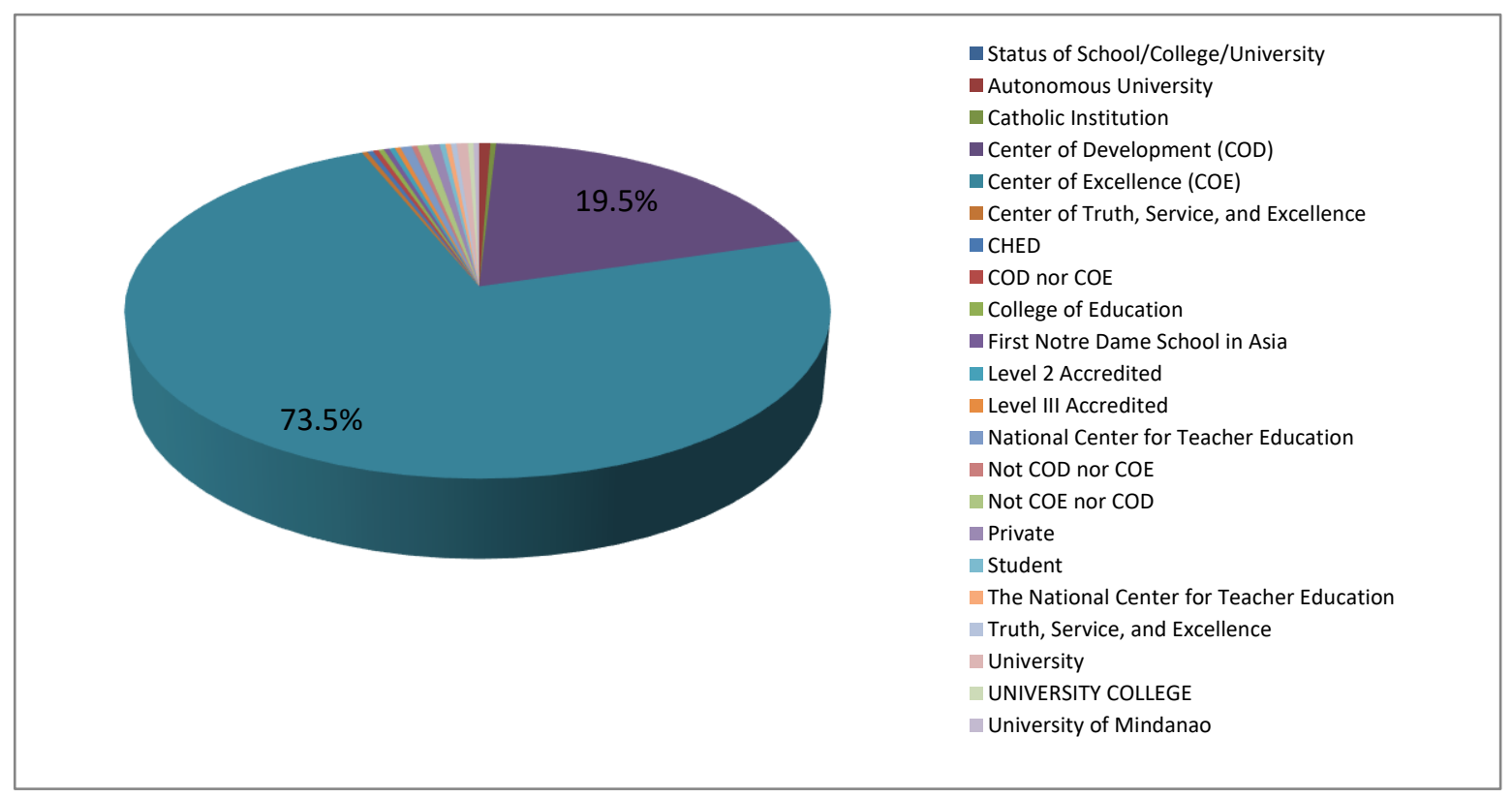

Figure 3: Status of School/College/University

(Source: Survey on The Preparedness of Pre-Service Teachers on the Required Teacher Preparation Programs to Meet Rigorous Standards) 
In terms, of the status of the school/college/university, $73.8 \%$ were from the Center of Excellence (COE) and 19\% were from the Center of Development (COD). The rest came from non $-\mathrm{COE} / \mathrm{COD}$ like private, autonomous, etc.

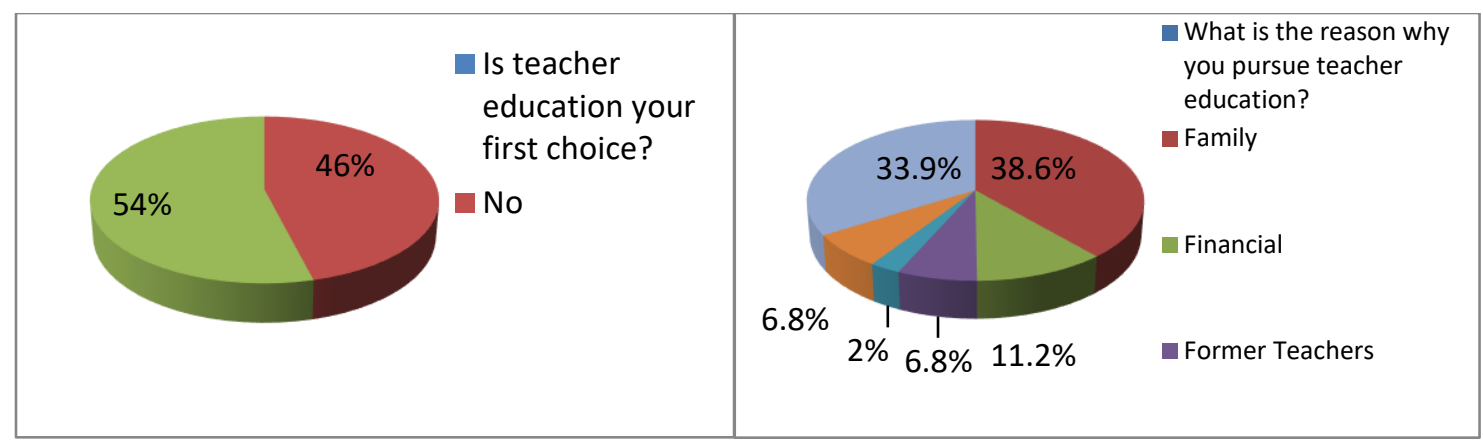

Figure 4: Interest to $T E$

Figure 5: Driving Force why pursue TE

(Source: Survey on The Preparedness of Pre-Service Teachers on the Required Teacher

\section{Preparation Programs to Meet Rigorous Standards)}

Figures 4 and 5 present the interest and driving force of the potential teachers to pursue teacher education. With the passion to teach, the pre-service teachers continue to equip themselves un their tertiary level to acquire the $21^{\text {st }}$-century education and be able to familiarize themselves and apply the $21^{\text {st }}$-century skills.

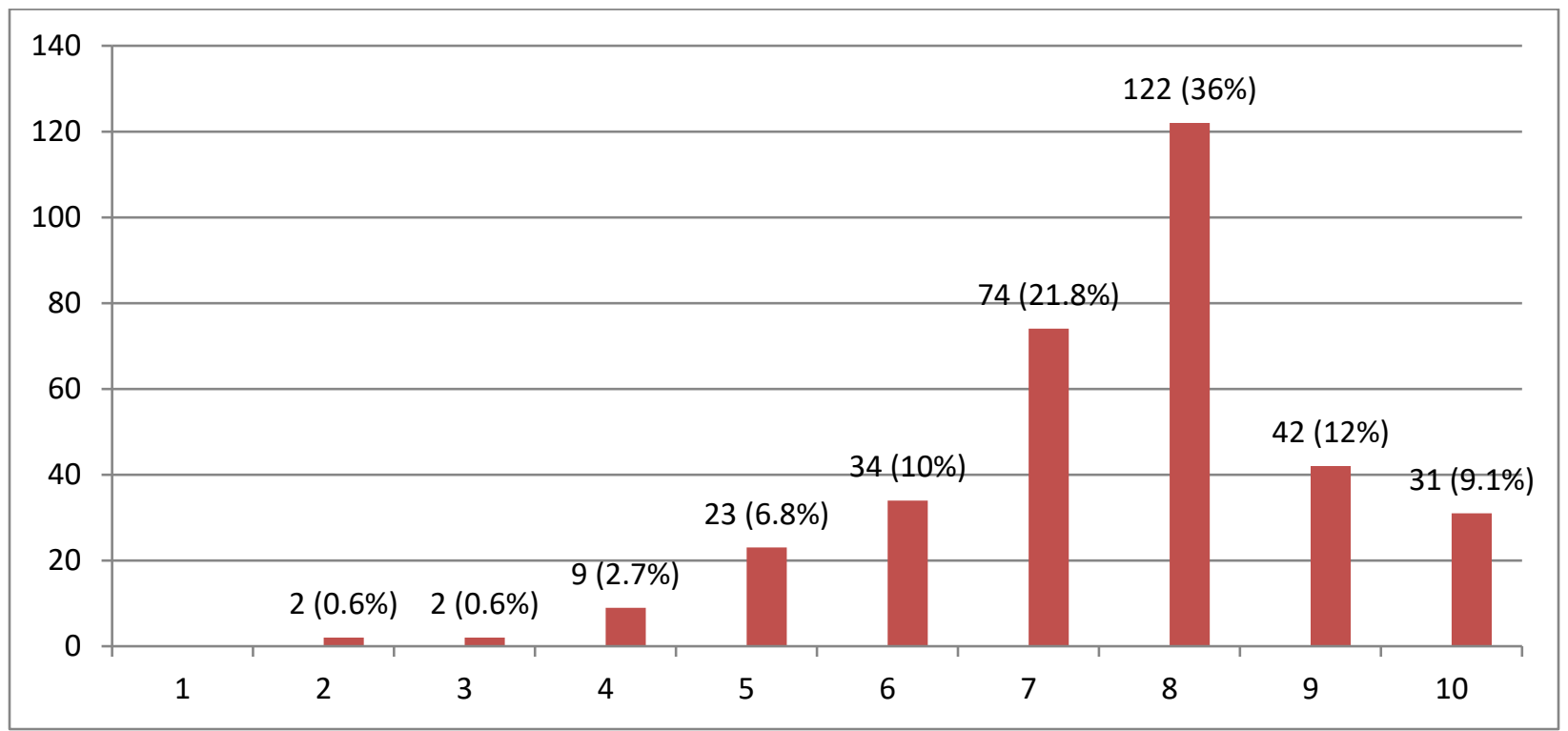

Figure 6: Level of Preparedness of the PSTs

(Source: Survey on The Preparedness of Pre-Service Teachers on the Required Teacher Preparation Programs to Meet Rigorous Standards) 
On the scale of 1 to 10,10 being the highest and 1 being the lowest, the PSTs stated their preparedness in entering their prospect school or station. 31.7 expressed that he/she's on level 8 of preparedness, whereas $23,8 \%$ that he/she's on level 7 of preparedness.

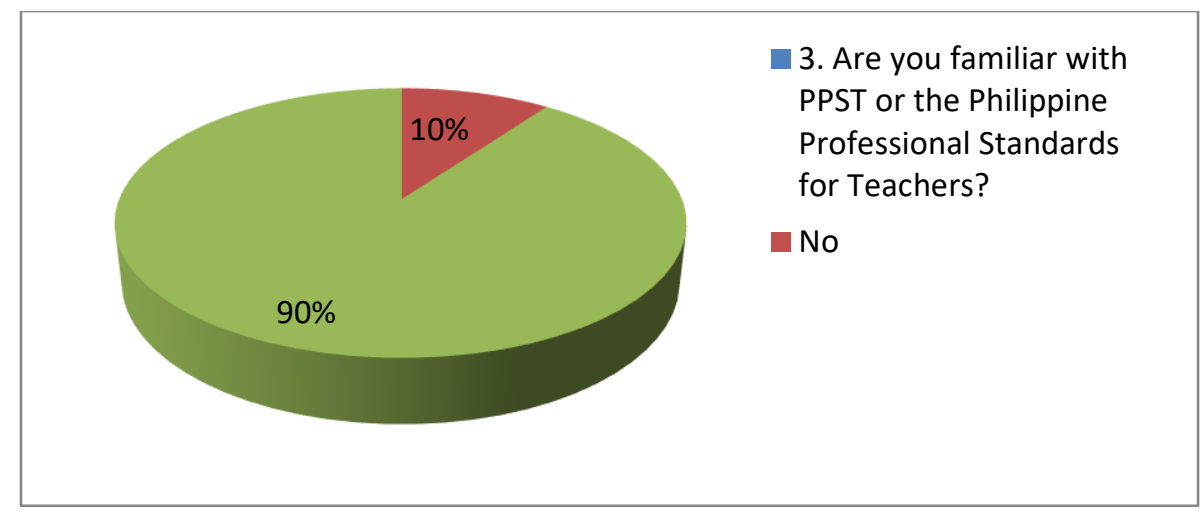

Figure 7: PPST Awareness

(Source: Survey on The Preparedness of Pre-Service Teachers on the Required Teacher Preparation Programs to Meet Rigorous Standards)

Figure 7 showed the percentage of familiarity of the pre-service teachers to the present professional standard followed by the Department of Education.

The second part of the discussion focused on the results of the one-on-one virtual interview. Out of five chosen participants for the interview, only three agreed to join in the conversation. The meeting lasted for 20 minutes (which was the longest duration) focused on five open-ended questions which were taken from the survey. This is the way for the researcher to validate and extract more from the participants on their ideas and thoughts on the matter.

The interview started with a short description of themselves. It was followed by their experiences as pre-service teachers during this pandemic in terms of the lesson, their internship, preparation as a graduating student, and preparation as a future teacher. Then, the different professional training they are looking forward to once they are already in the field. The PSTs shared about their learned theories and pedagogy which they think will be useful once they are already inside the classroom. And the last question focused on the challenges or dilemmas they encountered during this pandemic.

Participant 1 was a twenty-year-old pre-service teacher from NCR who pursued his studies through the help of a relative and a scholarship. The eldest among the four siblings and whose passion was teaching. He used to be the teacher way back in the old days when they are playing with cousins and friends. He had too much struggle and difficulty at the onset of the pandemic 
because he doesn't have any gadgets or internet at home. He was using his cellphone during online classes. He asked for help from a very close friend with a gadget at home and do the task for him. He explained and shared the idea with his friend and they communicated through messenger regarding the assignment or any output. He is looking forward to more professional training, he also heard about Learning Action Cell or LAC but doesn't have any idea yet on how they do it. He also expects that the school head and his future colleagues will encourage and support new teachers like him. He confided that his Alma Matter equipped him with the different strategies and techniques and taught him to have very long patience while in the field already. The main problems he encountered during the pandemic were the following: no gadget or device for the online class, a very unstable internet connection, too many tasks to do but no resources. But still survived and hopefully, he will be graduating soon.

Participant 2 was a twenty - four - year old pre-service teacher from Region VIII who also continued her studies because of scholarship. The eldest daughter of eight siblings who struggled much during this pandemic. But this situation doesn't stop her to reach her goal but instead motivated her to strive more. Her family was the reason why she took education. This is also her parents' want for her. Participant 2 doesn't have any gadgets at home neither internet connection nor even resources. Since she's a scholar, she asked her very close and favorite teacher to help her. She visited the school and volunteered to clean the faculty room to use the computer of the teacher in the office just to comply with the requirement needed in school. She is looking forward to many pieces of training when she's already a teacher because she saw her teachers doing such and attending a lot of training. So, she is preparing herself already that when she entered the field she will be attending a lot of training also. She wished to visit and attend training in Manila. She is also confident that her college prepared her with the different strategies and techniques, classroom management, and the attitude of good and effective teachers towards students was learned already. The main problems she encountered during the pandemic were the following: no gadget or device at home, no internet connection, and no resources.

Participant 3 was the youngest among the 3 siblings with a brother and a sister whose mother is a teacher from Region 3. She took teacher education because it's her passion and she was inspired by her mother. Not so difficult on her part because she was supported by her siblings and parents. The only problem she encountered was she cannot go out and stayed the whole time at home. She's aware that the school offered different pieces of training for teachers like SLAC or 
School Learning Action Cell as she heard it from her mother. Sometimes teachers were sent to attend training in other places which excites her to visit other places. Participant 3 learned the different pedagogies, teaching strategies, and techniques, tips in the proper way of handling students' attitudes, and different styles of classroom management. What enlivens her is seeing herself in front of the class lecturing, giving lessons as a teacher. She hopes that this pandemic will end soon so that everything will back to normal. She also struggles in a way that she faced situations regarding schoolwork alone. She also experienced that her stress and anxiety level also increase because she felt alone.

After the virtual interview, the participants have gathered again for the focus group discussion. A short sharing about their preparedness in facing the challenges of a classroom teacher once they are already deployed in the field, whether face to face or virtual. All of them planned to take the Licensure Examination for Teachers (LET) so they will take a review class, some will do a self-review and prepare for the exam. They are also planning to take a master's degree after the LET. They want to engage themselves also in research and innovation.

In terms of preparedness, Participant 1 believed that he is $85 \%$ ready to enter a school and be in front of the classroom with noisy students. According to him, he will apply whatever he learned from his observation. He is also nervous of his co-teachers because they might have a very high expectation from him and are a bit afraid of the different challenges that he might be encountering and he might have been caught unprepared. Participant 2 expressed that she is $80 \%$ to $90 \%$ ready to become a public servant. Since she is a scholar according to her it's payback time. She will try her best to become a good teacher. She will face everything and capacitate herself to be an effective teacher. She is planning to pursue a master's when she's in the service already. Participant 3 stated that she is $90 \%$ ready to become a teacher. It's in her blood to become a teacher. The school setup is no longer new to her because of her mother who is a teacher. She is excited about teaching young learners. She can't wait to enter the class and greet her pupils with a big smile every morning and she hopes that this pandemic will end soon.

\section{Conclusions}

Based on the findings of the study, the following conclusions are made:

- Most of the pre-service teachers in the country aged from 21 and 22 commonly came from institutions under the $\mathrm{COE}$ and followed by COD; 
- Even if it is believed that Teacher Education is just a second choice or last choice, based on the result of the survey, teacher education is their first choice and that they are to the course because that's their passion;

- The pre-service teachers were already familiar that there are existing programs offered by the department for the professional learning and development of teachers. continuing education, school learning action cells, in-service training, seminars, and workshops for upskilling and reskilling of the teacher were some of these programs. The PSTs are also familiar that the department encourages every teacher to conduct action research and do continuous improvement programs that may lead to innovation;

- With $21^{\text {st }}$-century education, the PSTs acquired the 21 st-century skills in which the respondents mentioned the different theories and pedagogy learned inside the classroom. The participants also mentioned their preparedness in the new normal having the familiarity of the different modalities used by the department during this time of pandemic;

- As a future servant and molder of the youth, the participants are planning to continue their post-graduate studies for them to be equipped with the new trends in teaching and for professional learning and development also;

- These future teachers are already confident and ready for the challenges that they will be facing when they are already on their station, and they are already inside the classroom / virtual classroom;

- Their tertiary education equipped the PSTs with the knowledge and skills that they will be using when they are already in the classroom. They are also expecting that they will be mentored when they are already in the school. And that continuous professional development and training may be open to all the teachers regardless of their tenure.

\section{Recommendations}

Based on the conclusions of this study, the following recommendations are forwarded:

- Encourage other TEIs to strengthen Teacher Education in their institution;

- Continue to support the potential teacher education students to pursue education 
with aid or scholarship.

- Strengthen the support of education agencies to the pre-service teacher for them to be equipped of the trend in the department.

- Education institutions and schools to offer training based on the need of the PSTs so that they will be useful and usable when they are already in their workplace.

- Offer a scholarship to interested students who will pursue their post-graduate studies.

- Boost self-confidence, self-esteem, and flexibility to face the challenges of the workplace by offering seminars on personality development before their graduation. Mentoring is also a good and great help to these PSTs.

- Thorough feedbacking during the internship, field study, and demonstration teaching for improvement. Training and seminar can be suggested also before the onboarding of the newly hired teacher to the department so that they will be resilient and confident to face the field or the workplace.

- A similar study can be conducted to further investigate and gain more knowledge regarding the matter and another study can be conducted in the future which may enhance the quality of this existing research.

\section{REFERENCES}

Ambler, T., Solomonides, I., Smallridge A., McCluskey, T. \& Hannah, L. (2020). Professional learning for academics teaching first-year undergraduate students. Professional Development in Education 46:5, pages 845-857. https://doi.org/10.1080/19415257.2019.1647272

Bailey, L. B. (2010). The Impact of Sustained, Standards-Based Professional Learning on Second and Third Grade Teachers' Content and Pedagogical Knowledge in Integrated Mathematics. Published Online. Springer Science Business Media, LLC 2010. https://doi.org/10.1007/s10643-010-0389-X

Binmohsen, S. A. \& Abrahams, I. (2020) Science teachers' continuing professional development: online vs face-to-face. Research in Science \& Technological Education 0:0 pages 1-29. https://doi.org/10.1080/02635143.2020.1785857 
Bjorke, Forland, Kjersti \& Moen. (2020). 'While we may lead a horse to the water, we cannot make him drink': three physical education teachers' professional growth through and beyond a prolonged participatory action research project. Sport, Education and Society 0:0, pages 1-14. https://www.tandfonline.com/doi/full/10.1080/13573322.2019.1574731?src=recsys

Brady, Kellyanne (2020). The Development of Professional Identity and the Impact of Counselor Educators: Examining the Role of Observational Learning and Self - Efficacy. Pace University, Pleasantville, New York. https://digitalcommons.pace.edu/dissertations/AAI28089400/

Brisk, M. E., \& Zisselberger, M. (2011). "We've let them in on the secret": Using SFL theory to improve the teaching of writing to bilingual learners. In T.Lucas, (Ed.), Teacher preparation for linguistically diverse classrooms: A resource for teacher educators (pp.111-126). New York: Routledge.

CHED Memorandum Orders 74-82, s. 2017. https://ched.gov.ph/wpcontent/uploads/2017/11/CMO-No.-74-s.-2017.pdf

Darling-Hammond, L., \& Young, P. (2002). Defining "highly qualified teachers": What does "scientifically-based research" actually tell us? Educational Researcher, 31(9), 13-25. https://doi.org/10.3102/0013189X031009013

Davis, S.L (2016). How Do Teacher Perceptions of the Six, Essential Professional Learning Community (PLC) Criteria Impact the Effectiveness of a PLC? Concordia University Library, Irvine, California. https://www.proquest.com/openview/4a787c44163764de912a4551eeef728a/1?pqorigsite $=$ gscholar $\& \mathrm{cbl}=18750 \&$ diss $=\mathrm{y}$

DepEd Order No. 42, s. 2017 The Philippine Professional Standards for Teachers. https://www.deped.gov.ph/wp-content/uploads/2017/08/DO_s2017_042-1.pdf

DepEd Order No. 43, s. 2017 Teacher Induction Program Policy. https://www.deped.gov.ph/wp-content/uploads/2017/08/DO_s2017_043-2.pdf

Executive Order 83, s. 2012. https://www.officialgazette.gov.ph/2012/12/17/implementing-rulesand-regulations-of-executive-order-no-83-s-2012/ file://C:/Users/asus/Downloads/Learning_2030_Beyond_Technolo.pdf 
Garcia, P. A., Moser, K. M., Davis-Wiley P. (2018). Facing reality: A survey of methods instructors' perspectives on world language teacher development. Foreign Language Annals, 2019;52:165-183. https://doi.org/10.1111/flan.12373

Glen, S., (2021). Research Methods: Qualitative Research and Quantitative Research from StatisticsHowTO.com Elementary Statistics for the rest of us! https://www.statisticshowto.com/research-methods-qualitative-research-and-quantitativeresearch/ https://www.deped.gov.ph/wp-content/uploads/2017/08/DO_s2017_042-1.pdf https://www.deped.gov.ph/wp-content/uploads/2017/08/DO_s2017_043-2.pdf https://www.literacyworldwide.org/docs/default-source/resourcehttps://www.officialgazette.gov.ph/2013/09/04/irr-republic-act-no-10533/

International Literacy Association 2020 Report on What's Hot in Literacy. https://www.literacyworldwide.org/get-resources/whats-hot-report

Jasso, L.K. (2018). Teacher Perceptions of Effective Instructional Coaching in Professional Development Support. School of Education Concordia University Irvine, California. https://eric.ed.gov/?id=ED592134

Mendenhall, Cha, Falk, Bergin, \& Bowden. (2021). Teachers as agents of change: positive discipline for inclusive classrooms in Kakuma refugee camp. International Journal of Inclusive Education 25:2, pages 147-165. https://doi.org/10.1080/13603116.2019.1707300

Mishra, S.B. \& Alok, S. (2017) Handbook of Research Methodology. Edu Creation Publishing, New Delhi, India. https://www.researchgate.net/publication/319207471_HANDBOOK_OF_RESEARCH METHODOLOGY

Moakes. (2021). 2-Curious: jarring representations of the two-year-old in transformative continuous professional development (CPD). Professional Development in Education 0:0, pages 1-14. https://doi.org/10.1080/19415257.2021.1879223

Nasser, Deghaidy, Heba \& Al-Shamrani, Saeed \& Aldahmash, Abdulwali. (2014). Rethinking the Theory and Practice of Continuing Professional Development: Science Teachers' Perspectives. Research in Science Education. 10.1007/s11165-014-9409-y. 
https://www.researchgate.net/publication/261892528_Rethinking the Theory_and_Pract ice_of_Continuing_Professional_Development_Science_Teachers'_Perspectives

Noida (2021). Educators: Reskilling \& upskilling is the need of the hour.

https://digitallearning.eletsonline.com/2021/04/educators-reskilling-upskilling-is-need-ofthe-hour/

O’Riordan, O’Sullivan, Fitzpatrick, Keane, McAvinia, \& Risquez. (2020) Structured professional development for academic developers: A collaborative approach. Innovations in Education and Teaching International 0: 0, pages 1-11. https://doi.org/10.1080/14703297.2020.1813189

OECD (2018). Education Policy in Japan: Building Bridges towards 2030. https://doi.org/10.1787/9789264302402-en

Owsiak, N.K., (2008). Teacher Quality Accountability Measures: Perceptions of Degree and Direction of Influence on University-based Teacher Education Programs. The George Washington University, Washington, DC. https://www.proquest.com/openview/9db397704c1b91be72b00eed453323d6/1?pqorigsite $=$ gscholar $\& \mathrm{cbl}=18750$

Pyne, C. (February 18, 2014), The Sidney Morning Herald, Online Memorial. https://www.smh.com.au/politics/federal/a-quality-education-begins-with-the-bestteachers-says-christopher-pyne-20140219-32z61.html

Republic Act 10533 (An Act Enhancing the Philippine Basic Education System) https://www.officialgazette.gov.ph/2013/05/15/republic-act-no-10533/

Rönnerman \& Olin (2021). Practice changing practices: influences of Master's program practice on school practices. Professional Development in Education 0:0, pages 1-17. https://doi.org/10.1080/19415257.2021.1910978

Schnabel, R. B., (2009). The Impact of Traditional and Alternative University Teacher Preparation Program Options on Secondary Teacher Candidates’ Knowledge, Skills, Dispositions, and Employment. Omaha, Nebraska. https://digitalcommons.unomaha.edu/studentwork/25/

Schrier, L.L. (2008). The Overwhelmed Generation and Foreign Language Teacher Preparation: Developing Strategies to Work with the Mental Health Challenges of Preservice 
Teachers. Foreign Language Annals; Summer 2008; 41, 2: Research Library pg. 282. https://doi.org/10.1111/j.1944-9720.2008.tb03293.x

Sox, A. K., (2011). Teacher Preparation for Instructing Middle School ELL Students: A North Carolina Piedmont Perspective. The University of Arizona. Tucson, Arizona. Strengthening Its Curriculum and Increasing the Number of Years for Basic Education. https://repository.arizona.edu/handle/10150/202755

Turner, C. J. (2015). Impact of Professional Learning Community Design on Teacher. https://scholarworks.uark.edu/cgi/viewcontent.cgi?article=1009\&context=etd

Wilson, S.M., Floden, R.E., \& Ferrini-Mundy, J. (2001). Teacher Preparation Research Current Knowledge, gaps, and recommendations (Document No. S-01-1). Michigan State University. http://depts.washington.edu/ctpmail/PDFs/TeacherPrep-WFFM-02-2001.pdf.

Wright, A.W. (2009). Reframing Professional Development Through Understanding Authentic Professional Learning. The University of Queensland. http://rer.aera.net https://www.gtcs.urg.UK/Professional-Update/Professional-Review-Development.Aspx 